\title{
Interleukin 4 Measurement
}

National Cancer Institute

\section{Source}

National Cancer Institute. Interleukin 4 Measurement. NCI Thesaurus. Code C74832.

The determination of the amount of interleukin 4 present in a sample. 